\title{
Redescription of Bradya typica Boeck, 1873 (Copepoda: Harpacticoida: Ectinosomatidae) with the first description of the male
}

\author{
Sybille Seifried · Gritta Veit-Köhler
}

Received: 1 August 2008 / Revised: 24 March 2009 / Accepted: 1 July 2009 / Published online: 24 October 2009

(C) Springer-Verlag and AWI 2009

\begin{abstract}
Bradya typica Boeck, 1873 is described from samples collected in the course of a colonisation experiment in Kongsfjorden, Spitsbergen (2003-2005). The male of $B$. typica, the type-species of the genus is described for the first time. B. typica can be distinguished from its congeners by its caudal rami (1.4 times longer than wide) and by its P5 (exopod longer than wide, inner terminal seta of exopod longest, inner seta of baseoendopod longer than outer one and surface seta rigid and curved). Variability within the species is rather small as only the length of some setae is slightly different. B. cladiofera Lang, 1965, B. congenera Sars, 1920, B. minutiseta Soyer, 1973 and B. pugiochaeta Arlt, 1983 are closely related to B. typica. Some details of the morphology, such as the body ornamentation and the longer hair-like pinnules on the spines of the swimming legs, are very difficult to observe even with maximum magnification. With certainty, B. typica is distributed near the Norwegian coast (Oslo Fjord to Trondheim Fjord), the Swedish coast (Skagerak to Öresund), around Spitsbergen and around the polar islands north of Grinnelland (Canadian Arctic Archipelago near Baffin Bay). Records of B. typica from the Kara Sea (near Novaya Zemlya), near
\end{abstract}

Communicated by H.-D. Franke.

S. Seifried $(\square)$

Faculty 5, Institute of Biology and Environmental Sciences,

AG Zoosystematics, University of Oldenburg,

26111 Oldenburg, Germany

e-mail: sybille.seifried@uni-oldenburg.de

G. Veit-Köhler

DZMB, German Centre for Marine Biodiversity Research, Senckenberg Research Institute, Südstrand 44,

26382 Wilhelmshaven, Germany
Franz Joseph Land, Iceland, Greenland, the British Isles and from deep waters of the North Sea have to be confirmed.

Keywords Bradya typica . Species redescription - Male . Spitsbergen

\section{Introduction}

Success of ecological studies on the species level is mainly dependent on reliable determination of the species found. As numerous descriptions of harpacticoid copepods are more than 100 years old, many important diagnostic details are lacking in the drawings. Type material is also often not accessible so that redescriptions on the base of new material are the best choice. This was the case for a species we found during our study of arctic benthic copepods.

Polar meiofauna communities are supposed to show extremely long colonisation and recovery times. This is especially relevant to defaunated zones in iceberg scours and newly ice-free areas which form in the course of glacial melting (Veit-Köhler et al. 2008). During a colonisation experiment of soft sediments in arctic glacial Kongsfjorden the recovery of meiofauna communities was observed on higher taxon level (for complete data see Veit-Köhler et al. 2006). At present, the copepods are being studied on the species level. Among the 38 harpacticoid species identified from the succession samples, ten species were Ectinosomatidae. Bradya typica Boeck, 1873 was the only representative of the genus Bradya Boeck, 1873, so far.

Lang (1944) subdivided the genus Bradya Boeck, 1873 into two subgenera, Bradya Boeck, 1873 and Parabradya Lang, 1944. Both subgenera were raised to genus rank in Seifried et al. (2007). To date, Bradya encloses the type 
species B. typica, 11 valid species and 1 species incertae sedis (Seifried and Martínez Arbizu 2008).

This paper provides a redescription of the female and the first description of the male of B. typica.

\section{Materials and methods}

During an in situ experiment on metazoan meiofauna colonisation and succession at Brandal $\left(78^{\circ} 56.88^{\prime} \mathrm{N}\right.$, $11^{\circ} 51.63^{\prime} \mathrm{E}$ ), situated in arctic glacial Kongsfjorden (Spitsbergen), soft sediment containers were deployed at a depth of $20 \mathrm{~m}$ and sampled after a 1-, 2- and 3-year immersion period between 2003 and 2005. Samples were taken from the experimental containers and the surrounding sediment with cylindrical push cores by a SCUBA diver. Details on sampling strategy and sample treatment are described by Veit-Köhler et al. (2008).

The material relevant to this paper is kept in the collection of the Forschungsinstitut und Naturmuseum Senckenberg, Frankfurt (Germany).

The individuals from Spitsbergen, outside Hornsund, were taken during the Swedish Arctic Expedition 1898 with the research vessel "Antarctic" (SMNH 91911, Swedish Museum of Natural History Stockholm, Harpacticoida Collection of K. Lang, tube no. 103). Sampling data: Swedish Arctic Expedition 1898 station no. 9, 26/6/1898, $76^{\circ} 90^{\prime} \mathrm{N}$, $14^{\circ} 40^{\prime} \mathrm{E}$, depth $210 \mathrm{~m}$, temperature $2.83^{\circ} \mathrm{C}$, very fine unmixed black-grey mud, det. K. Lang. The zoologists on board were G. Kolthoff and A. Ohlin.

The individuals from Gullmarn were collected by Karl Lang (SMNH 91910, Swedish Museum of Natural History Stockholm, Harpacticoida Collection of K. Lang, tube no. 102). Sampling data: Gullmarn near Lysekil, Gullmar Fjord, Sweden, May to October 1937, 20-60 m, mud, det. K. Lang.

The females from Risør, near the Oslo Fjord in Norway, were collected and determined by G.O. Sars (Natural History Museum, University of Oslo). No sampling data are available.

Drawings were made with the aid of a drawing tube on a Leica differential interference contrast microscope (DMLB with UCA condensor, IC prism and doubler $\times 1.5$ ).

The following abbreviations are used in the text: SMF = Forschungsinstitut und Naturmuseum Senckenberg; SMNH = Swedish Museum of Natural History Stockholm; P1-P6 = first to sixth leg; baseoenp = baseoendopod; enp = endopod $;$ exp = exopod $;$ enp $-1 \quad(2,3)=$ proximal (middle, distal) segment of endopod; exp-1 $(2,3)=$ proximal (middle, distal) segment of exopod; aes = aesthetasc.

The terminology is adopted from Seifried (2003). For setal homology and setae numbers, Seifried (2003) is followed here. The term groundpattern is used in the sense of "Grundmuster" and represents the hypothetical morphology of the members of the last common population of the species group in question.

\section{Results}

Ectinosomatidae Sars, 1903

Bradya Boeck, 1873

Bradya typica Boeck, 1873

Material from Spitsbergen kept in the Forschungsinstitut und Naturmuseum Senckenberg Female 1: dissected and mounted on 27 slides, coll. no. SMF 33613/1-27, Brandal, Kongsfjorden, Spitsbergen, $78^{\circ} 56.88^{\prime}{ }^{\prime} \mathrm{N}, 1^{\circ} 51.63^{\prime} \mathrm{E}$, depth of $20 \mathrm{~m}, 02.09 .2004$, experimental container 20, 2 -year exposure, sample 2 of 3 (Koldewey project KOP 51: Succession of benthic communities in polar environments). Male 1: dissected and mounted on 19 slides, coll. no. SMF 33614/1-19, 03.09.2004, experimental container 24, 2-year exposure, sample 3 of 3. Female 2: dissected and mounted on 16 slides, coll. no. SMF 33615/1-16, 02.09.2004, experimental container 20, 2-year exposure, sample 2 of 3. Male 2: dissected and mounted on 16 slides, coll. no. SMF 33616/1-16, 14.10.2005, ambient sample A2. Female 3: undissected, coll. no. SMF 33617, 02.09.2004, experimental container 20, 2-year exposure, sample 2 of 3. Male 3: undissected, coll. no. SMF 33618, 03.09.2004, experimental container 24, 2-year exposure, sample 3 of 3 .

Additional material from Spitsbergen Twenty females and 13 males from 2004 to 2005, same location, experimental containers 11 (06.09.2005, 3-year exposure), 14 (31.08.2004, 1-year exposure), 19 (07.09.2005, 3-year exposure), 20 (02.09.2004, 2-year exposure), 24 (03.09. 2004, 2-year exposure), and the ambient sample A2 (14.10.2005).

Museum material: Natural History Museum, University of Oslo, Crustacea Collection of G.O Sars Nine females in tube F 20044 (Risør, Norway), 1 female in tube F 20062 (Norway) and 3 females in tube F 20064 (one without abdomen; Risør, Norway).

Swedish Museum of Natural History Stockholm, Harpacticoida Collection of K. Lang Nine females in tube SMNH 91910 (Lang's number 102; Gullmarn, Gullmar Fjord, Sweden, 1937, depth of 20-60 m, mud) and 4 females in tube SMNH 91911 (Lang's number 103; Spitsbergen, outside Hornsund, 26.6.1898, $76^{\circ} 90^{\prime} \mathrm{N}, 14^{\circ} 40^{\prime} \mathrm{E}$, depth of $210 \mathrm{~m}$, temperature $2.83^{\circ} \mathrm{C}$, very fine unmixed black-grey mud).

Type locality Oslo Fjord (Boeck 1873). 


\section{Redescription of female}

All drawings made of female 1, except some details of ornamentation (Fig. 2e, g, h, j-o).

Body length (inclusive rostrum and exclusive caudal rami): $763 \mu \mathrm{m}$. Caudal rami: $60 \mu \mathrm{m}$. Maximum body width: $254 \mu \mathrm{m}$. Rostrum: $61 \mu \mathrm{m}$. Cephalothorax length (exclusive rostrum): $275 \mu \mathrm{m}$.

Body (Figs. 1a-d, 2a, d, f, i, p) with a distinction between prosome and urosome; prosome consisting of cephalothorax and 3 free pedigerous somites; first pedigerous somite completely fused to dorsal cephalic shield; urosome 5-segmented, comprising somite bearing P5, genital double-somite and 3 free abdominal somites; 1 egg-sac, 1 copulatory pore. Cephalothorax longer than wide and wider than urosome. Cephalothorax and body somites with sensilla and pores as figured (Figs. 1a, b, 2a). Whole body except cephalic shield, genital field and anal somite with rows of small setules (Figs. 1a, b, 2a); genital somite and 2 following somites ventrally with row of spinules (Fig. 2a, d, p). Anal somite covered with very small spinules (Figs. 1a, b, 2a). Hyaline frill of cephalothorax, penultimate somite and dorsal side of anal somite plain. Hyaline frill of 3 free pedigerous somites and all urosomal somites except the penultimate one serrate; indentation of the 3 free pedigerous somites very small (Fig. 1d), that of the first and anal somite small. Indentation of genital field and following somite deeper at the ventral than at the dorsal side (Fig. 2d, f), becoming deeper laterally (Fig. 2i). Hyaline frill of cephalothorax with strong reticulated subcuticular strengthening (Fig. 1c), that of the 3 free pedigerous somites with smaller reticulated subcuticular strengthening. Penultimate somite with pseudoperculum and a small protrusion of the hyaline frill at the ventral side, both with minute setules terminally. Anal somite divided.

Rostrum (Figs. 1a, b, 3a) nearly as long as broad; medially fused with cephalothorax; with 2 sensilla and 2 pores on dorsal surface and 2 sensilla on distal edge.

Genital field (Fig. 2a) with 1 median copulatory pore.

Caudal rami (Fig. 2a-c) 1.4 times longer than wide (length: measured ventral from the middle of the proximal edge to the inner beginning of the acuminate lappet/widest width), covered with small spinules and with 7 setae; posterior edge of rami terminating ventrally as acuminate lappet; setae I, V and VI unipinnate, seta IV with 2 rows of spinules at outer side of proximal third and unipinnate at distal two-third, setae II, III and VII bare.

Antennule (Fig. 4a) 7-segmented; armature formula: 1, $11,10+$ aes, $3,3,4,5+$ aes; all setae bare, proximal segment with 2 rows of spinules.

Antenna (Fig. 5a-c): coxa with row of very fine spinules; basis with long spinules at lateral edge; enp-1 with 1 bipinnate seta near proximal margin; enp-2 with 3 strong lateral and 6 strong distal setae; enp- 2 with 3 transverse rows of long spinules; exopod 3-segmented with 2, 1, 2 setae; exopod as long as endopod, middle segment shortest; exp-3 with long spinules at distal edge.

Labrum (Fig. 3b) not prominent; with a row of long spinules ventrally and with spinules at posterior edge.

Paragnaths (Fig. 5d, e) left and right paragnaths fused with many rows of setules and 2 rows and 3 fields of fine spinules on ventral and dorsal side; 3 strong spinules on dorsal side.

Mandible (Fig. 4b): cutting edge with 1 big and 7 smaller teeth, the 5 distal small teeth not fused to cutting edge; all teeth multicusped; 1 unipinnate seta at proximal and 1 bare seta at distal corner; coxal gnathobase with three rows of setules of different length; basis with 2 rows of setules, 2 fields of small spinules and 4 plumose setae; endopod 1-segmented with 3 setae laterally and $2+2+1$ apical setae, each group of apical setae basally fused, outer margin of endopod with fine long setules; exopod 1-segmented, shorter than endopod, with 4 lateral and 2 distal setae; exopod with 3 transverse rows of setules.

Maxillule (Fig. 6a, b): arthrite of praecoxa with 2 setae on anterior surface and apically with 4 spines and 2 setae, the 2 proximal spines fused to the praecoxa; coxa with 2 apical setae on a short endite; basis with $3+4$ setae on the endites; endopod with 6 setae; exopod with 2 setae; praecoxa, coxa, basis and exopod with rows of long setules and fields of fine spinules.

Maxilla (Fig. 6c, d): syncoxa with 3 endites with $(2+2)$, 2, 3 setae, row of spinules on anterior surface and field of small spinules on anterior and posterior surface each; proximal endite syncoxa with anterior spinules row; allobasis with 1 spine and 6 setae at distal edge and with anterior spinules row; endopod 3-segmented; armature formula: I, I + 1, 4.

Maxilliped (Fig. 6e): syncoxa with 2 bipinnate coxal setae at inner and outer distal corner and 2 rows of spinules; inner seta longer than syncoxa, basis and endopod together; endopod fused to basis at an angle; fused basis slightly longer than wide, without setae but with 1 semicircular row of spinules along inner edge and of long setules along outer edge; fused endopod with 2 lateral and 2 distal setae.

Armature formula P1-P4:

\begin{tabular}{lllll}
\hline & coxa & basis & exopod & endopod \\
\hline P1 & $0-0$ & $1-\mathrm{I}$ & I-0; I-1; III-I + 1-1 & $0-1 ; 0-1 ; \mathrm{I}-\mathrm{II}-2$ \\
P2 & $0-0$ & $1-0$ & I- 1 ; I-1; III-II-2 & $0-1 ; 0-1 ;$ I-II-I + 1 \\
P3 & $0-0$ & $1-0$ & I-1; I-1; III-II-3 & $0-1 ; 0-1 ;$ I-II-I + 2 \\
P4 & $0-0$ & $1-0$ & I-1; I-1; III-II-3 & $0-1 ; 0-1 ;$ I-II-I + 1 \\
\hline
\end{tabular}

Pl (Fig. 7a): coxa and basis with rows of small spinules and each with 1 pore; basis with 1 row of spinules at base of exopod and a row of long setules at inner distal corner; endopod longer than exopod; enp-3 longer than enp-1; 


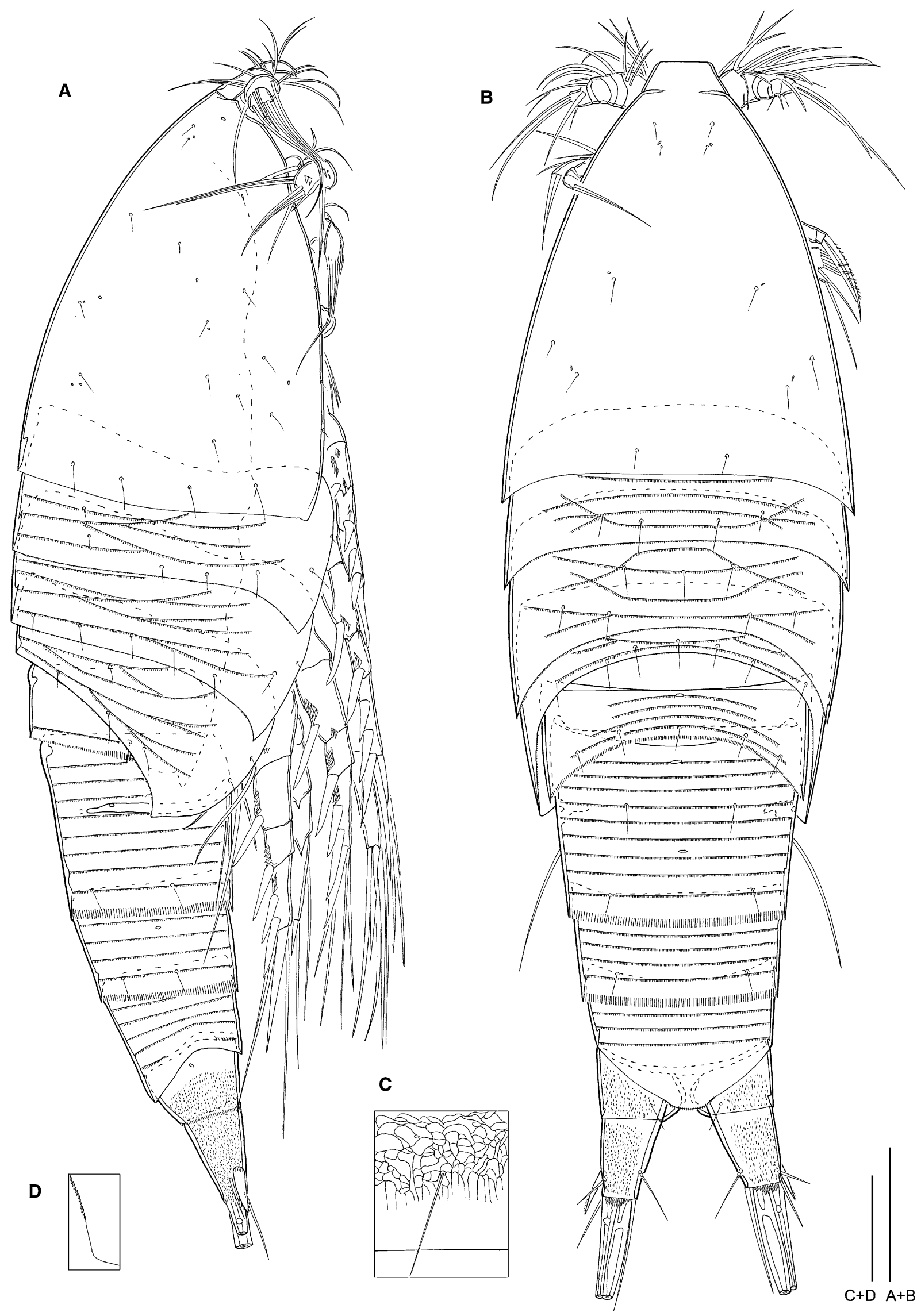


4 Fig. 1 Bradya typica Boeck, 1873, female 1: a habitus lateral; see paragraph "Note"; b habitus dorsal; see paragraph "Note"; c detail of hyaline frill of cephalothorax with strong reticulated subcuticular strengthening; $\mathbf{d}$ detail of lateral corner of hyaline frill of first free pedigerous somite. Scale bars $\mathbf{a}, \mathbf{b}=100 \mu \mathrm{m}, \mathbf{c}, \mathbf{d}=20 \mu \mathrm{m}$

outer margin of each segment strongly spinulose; anterior surface of enp-1-3 and posterior surface of enp-2-3 with rows of short or long spinules; enp-2 and enp-3 with pore; exp-3 longer than exp-1; outer margin of each segment spinulose; anterior surface of exp-1-3 with rows of spinules; inner margin of exp-1-2 with a row of setules; exp-2 with pore; inner seta of exp-2 with conspicuous setules at the tip.

$P 2-P 4$ (Figs. 7b, 8a, b): coxa with rows of small spinules on anterior surface and a row of spinules at distal margin; basis with 1 row of spinules at base of exopod, 1 row of spinules near inner distal corner and a row of long setules at inner distal corner; the spinules near inner distal corner are longest in P2 and shortest in P4; coxa and basis each with 1 pore; endopod as long as exopod in P3 and P4, but endopod longer than exopod in P2; enp-3 much longer than enp-1; anterior surface of enp-1-3 and posterior surface of enp-2-3 with rows of short or long spinules; outer margin of each segment strongly spinulose; anterior surface of enp- 1 with 1 row of very long setules; enp- 2 and enp-3 with pore; distal inner element of enp-3 developed as long spine; exp-3 longer than exp-1; anterior surface of exp-1 with 1 row of strong setules; anterior surface of exp-1-3 with rows of small spinules and outer margin spinulose; inner margin of exp-1 with a row of setules; exp-3 with pore; inner seta of exp- 2 with long and conspicuous setules at the tip; proximal inner seta of exp-3 P4 transformed to curved seta with a strong basis.

P5 (Fig. 9a, d): left and right P5 separated; exp longer than wide; exp with 3 terminal setae and 1 surface seta, inner terminal seta bipinnate with a double tip and longest, middle terminal seta and surface seta unipinnate, outer terminal seta bare; surface seta rigid and curved; small spinules at base of surface seta; baseoendopod with 2 setae on inner part, innermost seta tripinnate and longer, outermost bipinnate with a double tip; 1 bare seta and 1 pore on outer part of the baseoendopod.

P6 (Fig. 2a) with 1 seta.

\section{Description of male}

All drawings made of male 1. Mouthparts, antenna, labrum, paragnaths, armature formula $\mathrm{P} 1-\mathrm{P} 4$ and caudal rami as in female.

Body length (inclusive rostrum and without caudal rami): $653 \mu \mathrm{m}$. Caudal rami: $49 \mu \mathrm{m}$. Maximum body width: $219 \mu \mathrm{m}$. Cephalothorax length (exclusive rostrum): $257 \mu \mathrm{m}$. Spermatophore: $83 \mu \mathrm{m}$.
Body (Figs. 2e, g, h, j-m, 10a, b) as in female but urosome 6-segmented, consisting of somite bearing P5 and 5 abdominal somites; indentation of the hyaline frill of 2 nd to 4th urosomal somites not so deep as in female (Fig. 2e, g, h, j); ventral row of spinules of 2 nd to 5 th urosomal somites bigger than in female and partly with space between the spinules (Fig. 2e, 1-o); penultimate somite laterally with spinules on the hyaline frill (Figs. 2k, 10a, b); 1 spermatophore.

Antennule (Figs. 9c, 11a, b) 7-segmented, with geniculation between segments 5 and 6; armature formula: 1, 1, 12, $8,15+$ aes $/ 4,9+$ aes; 1 seta with one big spinule (segment 3), 3 setae plumose (segments 5-7), other setae bare; 1 seta of the 5th segment and 3 setae of the 6th formed as short blunt spines; the cuticular cone of Ectinosomatidae on the 5 th segment comprises a unipinnate seta and 2 cuticular conical apophyses (Fig. 9c).

$P 1$ : armature formula as female; the rows of small spinules at the inner corner and in the middle of basis are longer than in female; the spinules of inner basis setae are as long as the long spinules of female on both sides; the field of small spinules on the distal anterior surface of enp- 1 is lacking; the anterior rows of spinules distal on enp- 2 and basal on enp- 3 consist of long spinules; there is 1 additional row of big spinules on posterior basal surface of enp-2; anterior surface of exp-2-3 with rows of long spinules; otherwise as in female.

$P 2-P 4$ : armature formula and ornamentation as female; enp-2 with pore near the outer insertion point of enp-3.

P5 (Fig. 9b): left and right P5 fused; exopod with 3 terminal setae and 1 surface seta, innermost seta with a double tip and slightly longer than the middle seta; baseoendopod with 2 setae on inner part, both with a double tip and outer seta very small.

P6 (Fig. 9b) symmetrical; with 3 setae, 2 rows of long spinules at the base and 3 rows of tiny setules distally.

Note

The ornamentation of the body is very difficult to see. A minimum magnification of 1,250 is necessary to see traces of the rows of small setules (Figs. 1a, b, 2a). Often the object of study has to be observed from different angles to discern the complete ornamentation. The longer hair-like pinnules on the outer and distal spines of the exopod and enp-3 of P2-P4 are relatively wide, but very hyaline and flexible. They tend to cling to the spine and usually only the insertion point is therefore visible.

\section{Variability}

Body length of females varies between 730 and 1,080 $\mu \mathrm{m}$ $($ mean $=860 \mu \mathrm{m} ; n=15)$. The males vary between 570 and 


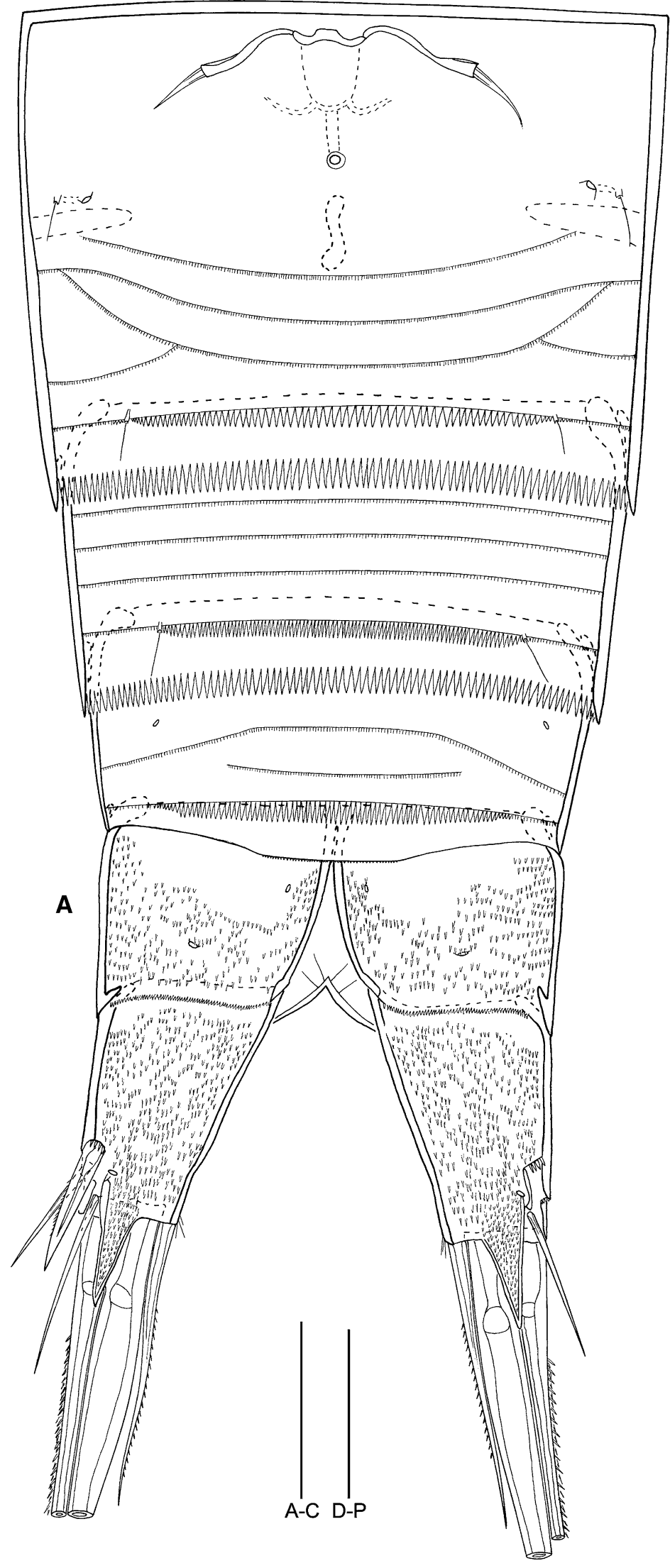

B

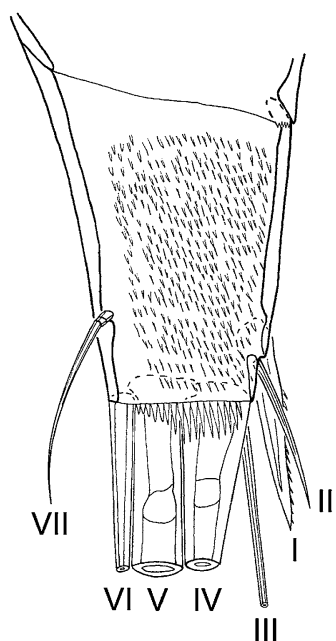

D

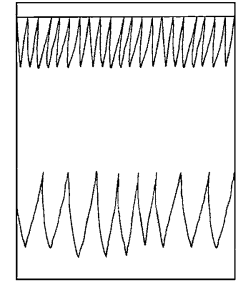

C

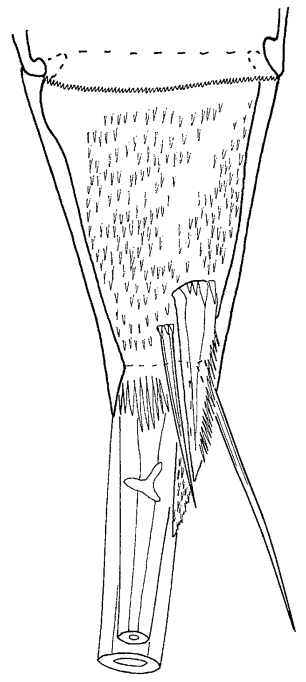

E

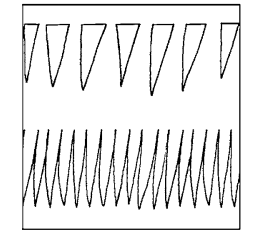

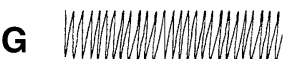

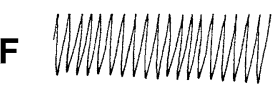

H numunumunumun

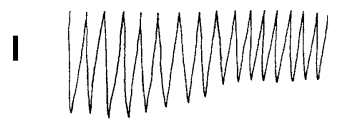

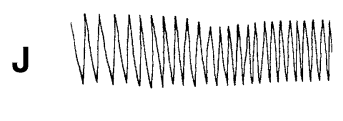

L WWW

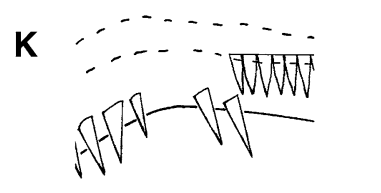


4 Fig. 2 Bradya typica Boeck, 1873, a female 1: abdomen with genital field, ventral; see paragraph "Note"; b female 1: caudal ramus dorsal; c female 1: caudal ramus lateral; $\mathbf{d}$ female 1: detail of hyaline frill and row of spinules of genital somite; e male 1: detail of hyaline frill and row of spinules of genital somite; $\mathbf{f}$ female 1: detail of dorsal hyaline frill of genital somite; $\mathbf{g}$ male 1: detail of dorsal hyaline frill of second urosomal somite; $\mathbf{h}$ male 1: detail of dorsal hyaline frill of fourth urosomal somite; i female 1: detail of lateral hyaline frill of genital somite; j male 1: detail of lateral hyaline frill of third urosomal somite; $\mathbf{k}$ male 1: detail of hyaline frill and spinule row of lateral penultimate somite. Details of spinules row of lateral penultimate somite: $\mathbf{I}$ male $1 ; \mathbf{m}$ male 1, other side; $\mathbf{n}$ male $3 \mathbf{o}$ male 2; $\mathbf{p}$ female 1 . Scale bars $\mathbf{a}-\mathbf{c}=50 \mu \mathrm{m}$, $\mathrm{d}-\mathrm{p}=20 \mu \mathrm{m}$

$690 \mu \mathrm{m}($ mean $=634 \mu \mathrm{m} ; n=11)$. The spinule rows of the penultimate somite of male consist laterally of spinules with different lengths and strengths (Fig. 21-o).

Compared with the females from Spitsbergen from 2004 to 2005 (Figs. 1, 2, 3, 4, 5, 6, 7, 8, 9), the seta on enp-1 of the antenna is one third longer, the long bipinnate lateral seta on enp- 2 of the antenna is as long as the long outermost distal seta of enp-2, and the setules on the inner terminal corner are three times longer in females of Gullmarn (Sweden, 1937, SMNH 91910). The inner setae of enp-1-2 of P1 and enp-1 of P2-4 are one-third shorter in females from Spitsbergen sampled in 1898 (SMNH 91911) than in females sampled in Spitsbergen in 2004 and 2005. The ventral row of spinules and the hyaline frill of genital somite and two following somites of the females from Risør ( $F$ 20044) correspond with those of the male from Spitsbergen from 2004 and 2005 (Fig. 2e). In females of the G.O. Sars Collection, the ornamentation of the body is covered with fine dirt. Therefore, the fine details of ornamentation are not visible. No males are in the collections of G.O. Sars and K. Lang for comparison.

\section{Discussion}

\section{Material}

No type material of Boeck (1873) is left, but we have examined the material on which Sars (1904) may have based his description of the female of B. typica, which is the type-species of the genus. The females Boeck (1873) used for the original description came from the Oslo Fjord, Norway (Boeck 1873; Lang 1948). Some of the specimens Sars (1904) probably used for his description, and which we re-examined came from Risør, near the Oslo Fjord (tubes F 20044, F 20064). The females from our samples at Spitsbergen (from 2004 to 2005; Figs. 1, 2, 3, 4, 5, $6,7,8,9)$ have exactly the same morphology as these females from Risør. Looking at Sars' figures (1904), there are some differences as compared to the specimens in his collection (tubes F 20044, F 20064). Sars (1904) described the exopod of the mandible with five setae, but all specimens we observed have six (as in Fig. 4b). Sars (1904) drew the third lateral seta of the endopod of mandible as being situated near the basis as in Parabradya species (Seifried et al. 2007), but all three setae are in the middle of segment (as in Fig. 4b). Additionally, there are always three lateral setae on enp-2 of antenna (as in Fig. 5c), not two of them, there are some more setae on praecoxa and basis of the maxillule (as in Fig. 6a, b) and the endopod of maxilliped is fused with the basis (as in Fig. 6e). As Lang (1965) described, in contrast to Sars (1904), the endopod of maxilla of B. typica has two big claws (not one), the exp-3 of P4 three inner setae (not two) and the enp-3 of P4 one inner spine and one seta (not one spine and two setae). We also examined females which Lang (1936a, 1948) collected in Spitsbergen and Gullmarn (Sweden, not far from the Oslo Fjord) and observed only differences in the length of some setae compared to the females collected in Spitsbergen from 2004 to 2005 (see variability). The females from near Kong Karls Land $\left(78^{\circ} 50 \mathrm{~N} / 27^{\circ} 39 \mathrm{E}\right)$ and from the Siebeninseln (Sjuøyane, $81^{\circ} 14 \mathrm{~N} / 22^{\circ} 50 \mathrm{E}$ ) listed by Lang (1936a), were only recently found in K. Lang collection at Swedish Museum of Natural History Stockholm and are now catalogued under register No. SMNH 99272 and 99273.

Huys et al. (1996) presented figures of the dorsal habitus, antenna, mouthparts, P1 and female P5 of B. typica, but they did not mention where this specimen came from. As they give no details of the ornamentation of the body, a comparison is not possible. On the assumption that Huys et al. (1996) did not present certain details (such as the ornamentation of some setae and spines and rows of setules and spinules), the morphology of their specimen is the same as that used here for a redescription. The only differences are that the long inner seta on the syncoxa of the maxilliped is not bipinnate but plumose with longer hairlike pinnules, and that the form of the P5 exopod and the length of its setae are slightly different.

First description of the male of B. typica

The male of B. typica shows the typical sexual dimorphism of Ectinosomatidae which concerns body size, genital segmentation, antennule, P5 and P6. In addition, the ornamentation of the body and P1 is slightly different than in the female.

Species morphology and discrimination

As mentioned in the paragraph "Note" (see above), the ornamentation of the body and the longer hair-like pinnules on the spines of the swimming legs are very difficult to discern even with maximum magnification. Often, a specimen 
A

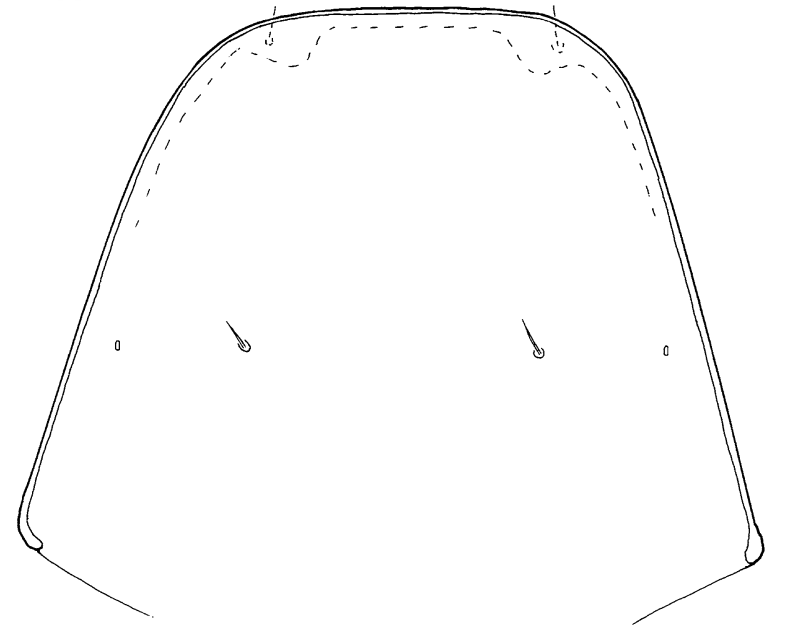

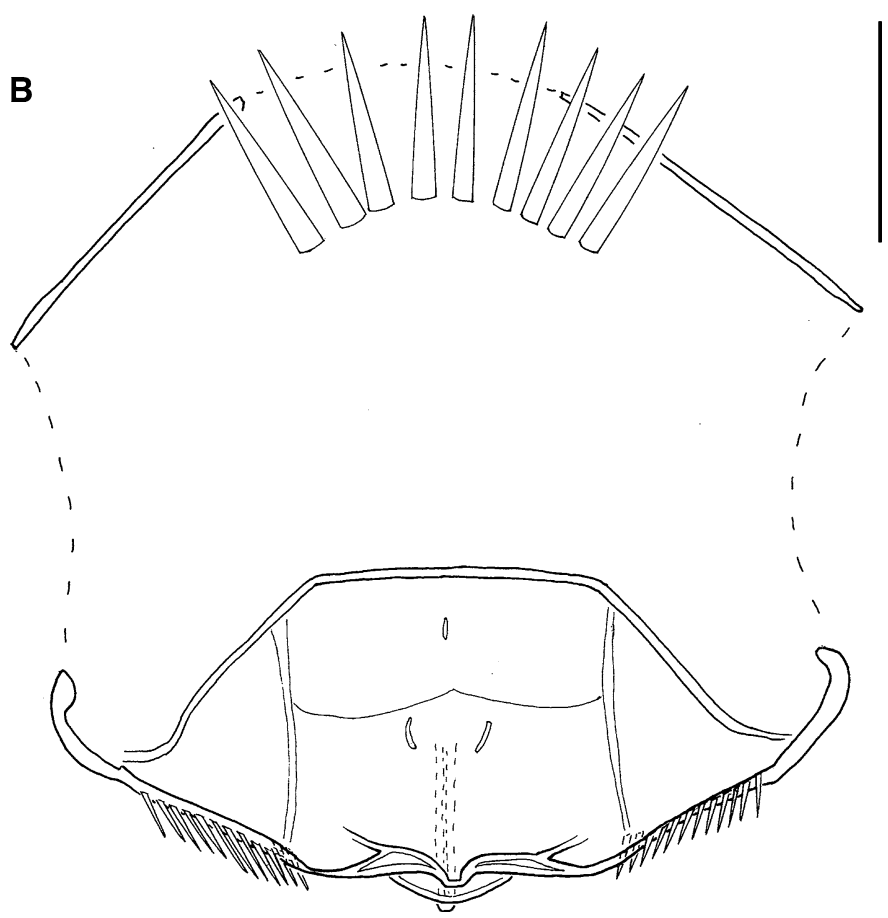

Fig. 3 Bradya typica Boeck, 1873, female 1: a rostrum; b labrum. Scale bar $=20 \mu \mathrm{m}$

has to be observed from different angles to see the body ornamentation and it has to be dissected to see the hair-like pinnules. The difficulties in detecting these structures are probably the reason, why they are not mentioned in the older descriptions of B. typica and other Bradya species.

Bradya typica can be distinguished from its congeners (Table 1) by the dimensions of its caudal rami (1.4 times longer than wide) and by the structure of its P5 (exopod longer than wide, inner terminal seta of exopod the longest, inner seta of baseoendopod longer than outer one, surface seta rigid and curved).

The descriptions of all Bradya species are incomplete (apart from that of B. kurtschminkei), and especially the detailed ornamentation of the body has not been described. These deficiencies restrict the possibility of comparison. B. typica shares the same armature formula of the swimming legs with eight of the other 11 Bradya species (i.e. B. cladiofera, B. congenera, B. macrochaeta Sars, 1920, B. minutiseta, B. pugiochaeta Arlt, 1983, B. scotti Sars, 1920, B. simulans Sars, 1920, B. theodori Soyer, 1973). The remaining three Bradya species have different setal formulae and can be distinguished as follows.

Bradya proxima Scott, 1912 has two setae less on P3 (i.e. one inner seta on exp-3 and enp-3), caudal rami that are shorter than wide and a characteristic P5 (the two setae of the baseoendopod and the two inner setae of the exopod of nearly the same length). B. furcata Sars, 1920 has one seta less on enp-3 of P3 and has one additional seta on enp-2 of P2. Further, the structure of P5 and caudal rami are very different from those in B. typica (see below). B. kurtschminkei Seifried and Martínez Arbizu, 2008 has many unusual and distinctive characters for example, the armature formula of P1-P4, as there are seven setae less at the endopods than in all other species of Bradya (Seifried and Martínez Arbizu 2008).

In contrast to B. typica (Table 1), the middle apical seta of the female P5 exopod is longest in B. furcata, B. macrochaeta, B. scotti, B. simulans and B. theodori, or it is nearly equal in length as the inner seta in B. proxima. B. macrochaeta can be distinguished from all other described $\mathrm{Bra}$ $d y a$ species by the excessive length of the P5 setae, which reach the caudal rami (body length $600 \mu \mathrm{m}$ ). Furthermore, both $B$. scotti (body length $880 \mu \mathrm{m}$ ) and $B$. simulans (body length $610 \mu \mathrm{m}$ ) have a square P5 exopod and their middle apical seta of the female P5 is strong and the longest of all P5 setae. However, the caudal rami of $B$. scotti are slightly (1.1 times) longer than wide, whereas those of $B$. simulans are 1.9 times longer than wide. The exopod of P5 of B. theodori is longer than wide and the inner seta of the baseoendopod is the strongest and longest of all P5 setae. The caudal rami of $B$. theodori are as long as wide (body length $471-495 \mu \mathrm{m})$.

In B. cladiofera, B. congenera, B. kurtschminkei, B. minutiseta and B. typica, the inner terminal seta of P5 exopod of female is the longest. In all other species of Bradya, either the middle seta is the longest or the two 


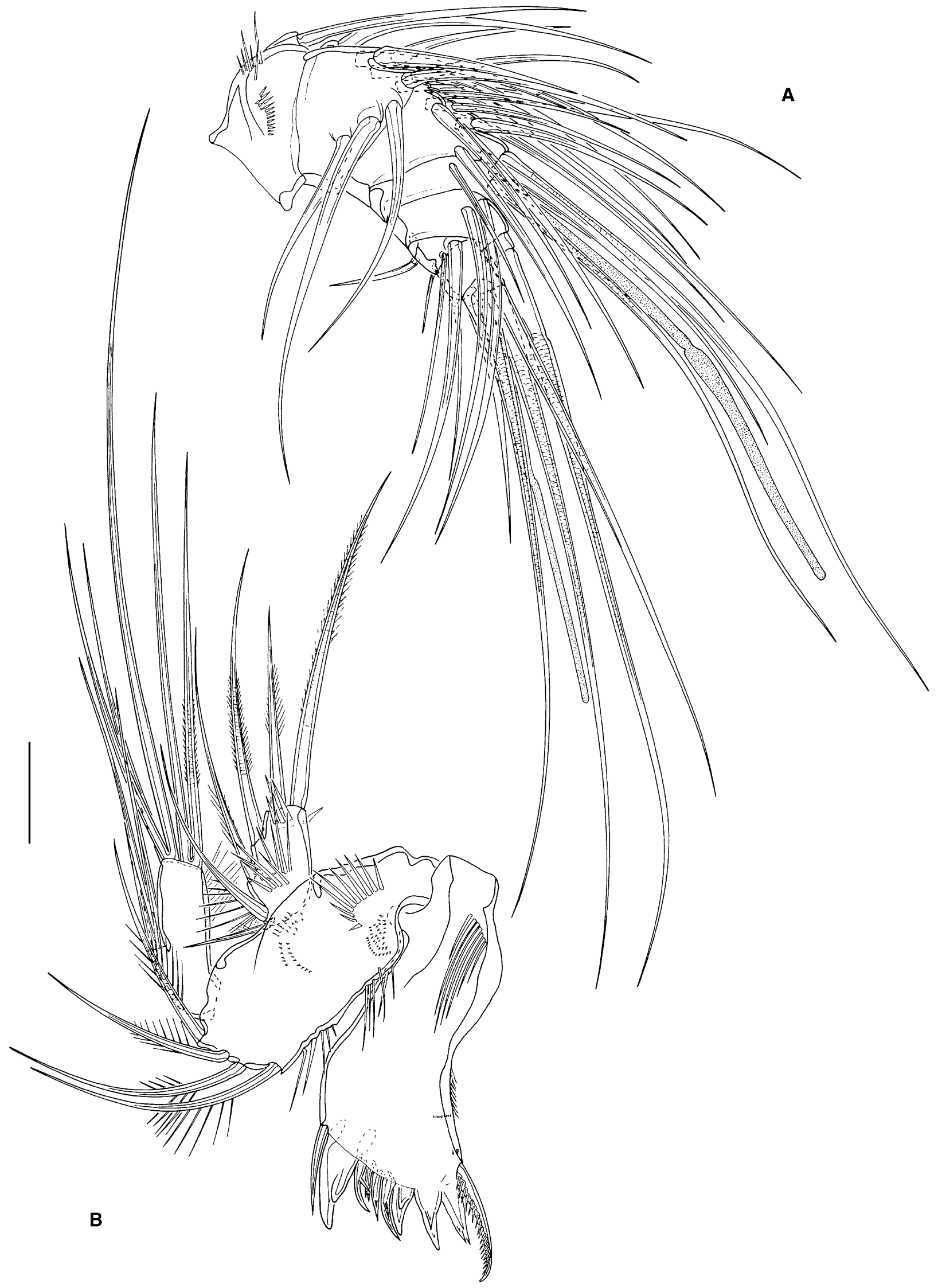

Fig. 4 Bradya typica Boeck, 1873, female 1: a antennule, dorsal b mandible. Scale bar $=20 \mu \mathrm{m}$ 


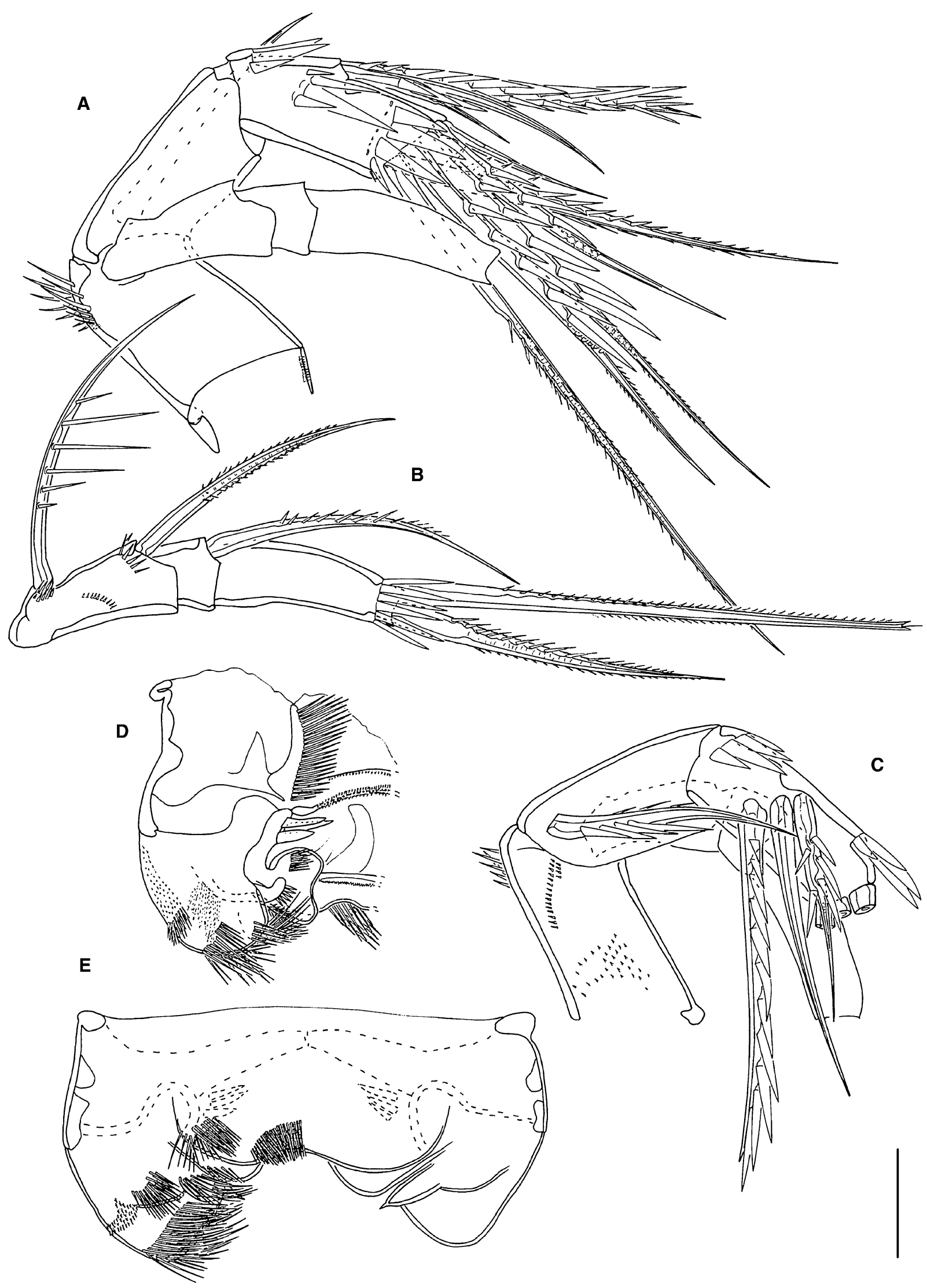

Fig. 5 Bradya typica Boeck, 1873, female 1: a right antenna, setae of exopod omitted; b exopod of antenna; c left antenna, setae of exopod omitted; $\mathbf{d}$ half part of fused paragnaths, dorsal side; $\mathbf{e}$ ventral side of paragnaths, setules of one-half omitted. Scale bar $=20$ 


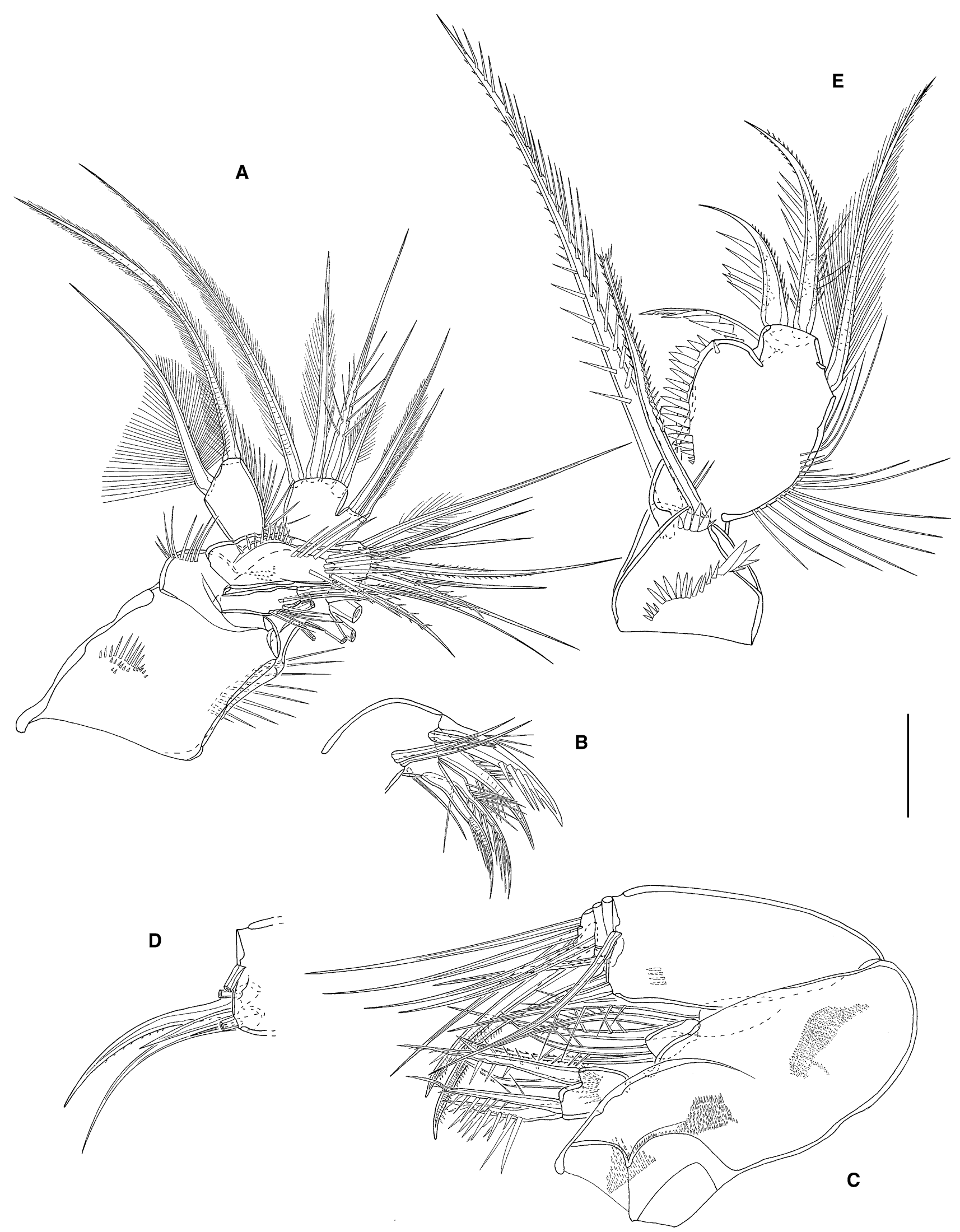

Fig. 6 Bradya typica Boeck, 1873, female 1: a maxillule, setae of arthrite of praecoxa omitted; $\mathbf{b}$ arthrite of praecoxa of maxillule; c maxilla posterior; $\mathbf{d}$ distal setae of allobasis of maxilla, posterior; $\mathbf{e}$ maxilliped. Scale bar $=20 \mu \mathrm{m}$ 


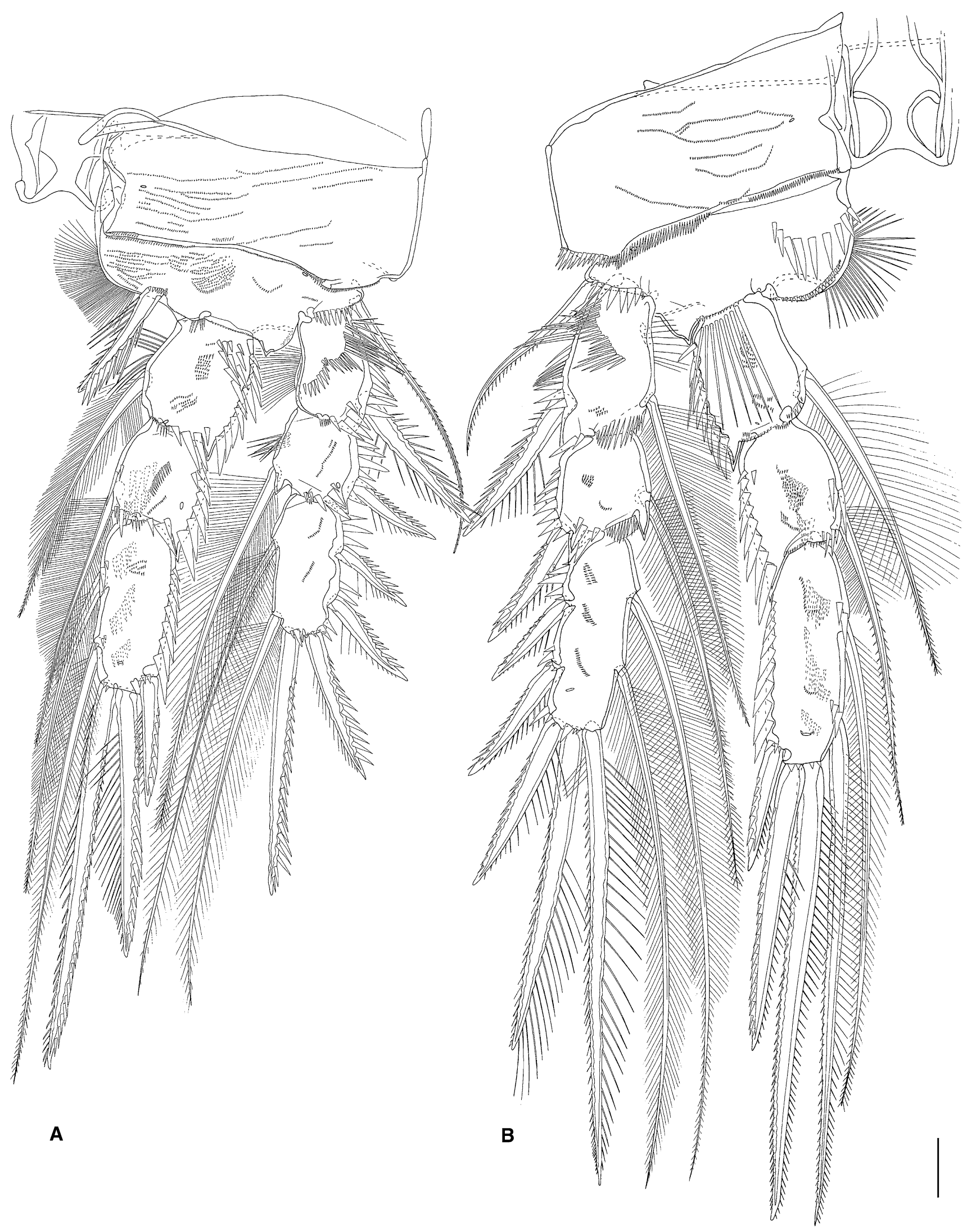

Fig. 7 Bradya typica Boeck, 1873, female 1: a P1; b P2; see paragraph "Note." Scale bar $=20 \mu \mathrm{m}$ 


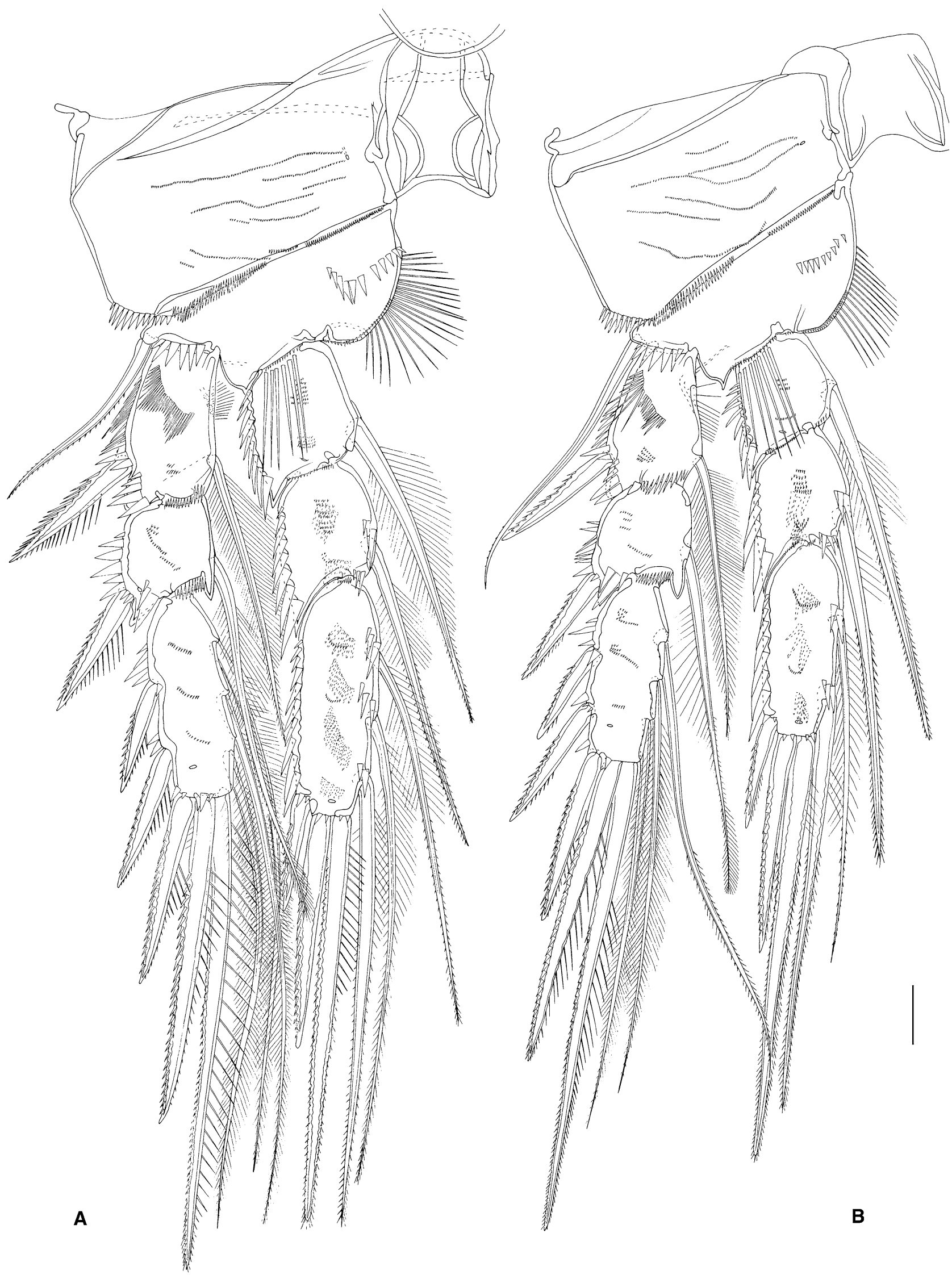

Fig. 8 Bradya typica Boeck, 1873, female 1: a P3; see paragraph "Note"; b P4; see paragraph "Note." Scale bar = $20 \mu \mathrm{m}$ 


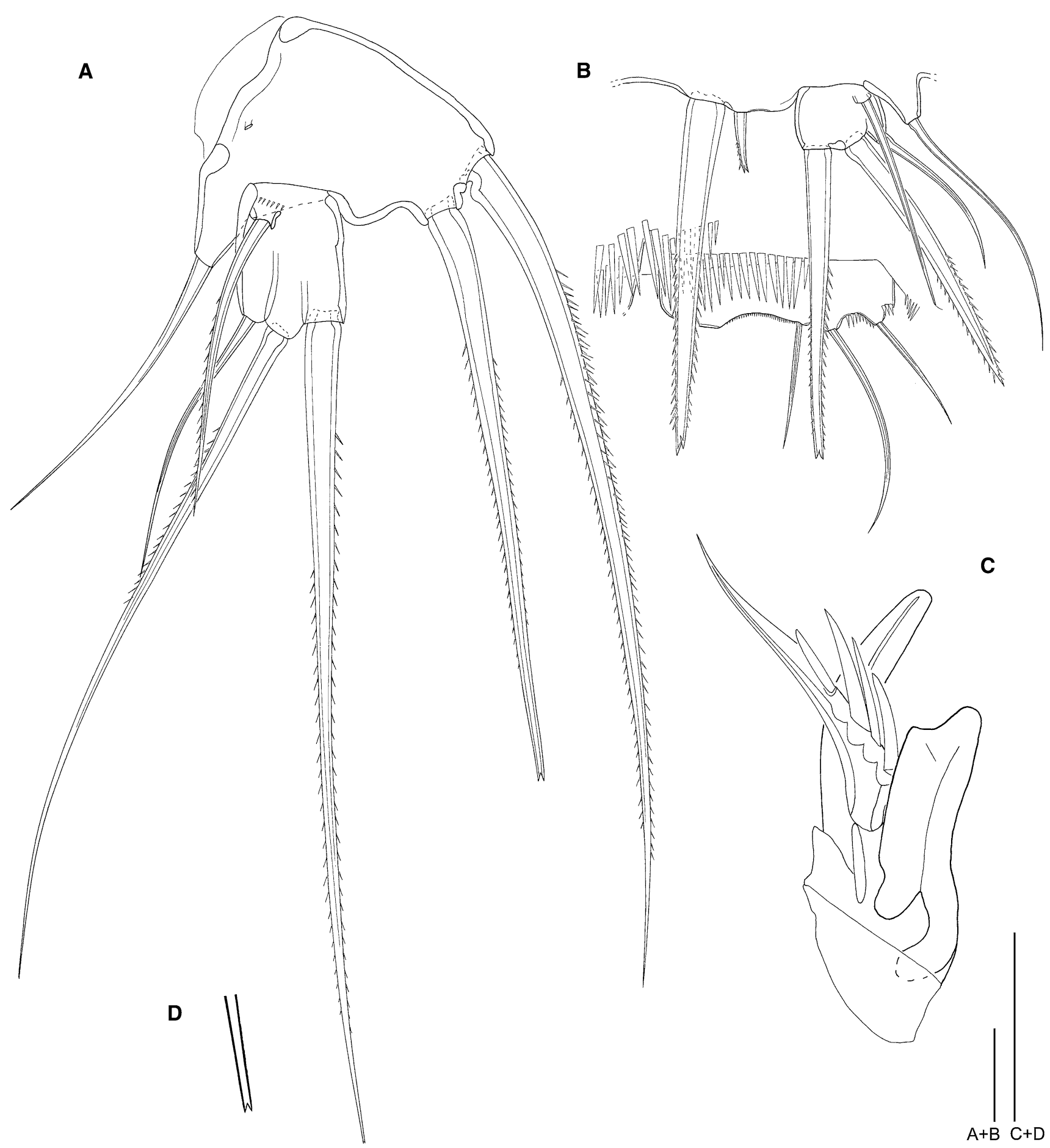

Fig. 9 Bradya typica Boeck, 1873, a female 1: P5; b male 1: P5 and P6; c male 1: cuticular cone on the fifth segment of antennule; d female 1: tip of inner seta of exp P5. Scale bars $\mathbf{a}, \mathbf{b}=20 \mu \mathrm{m}, \mathbf{c}, \mathbf{d}=10 \mu \mathrm{m}$

innermost setae have the same length. $B$. cladiofera, $B$. congenera and $B$. minutiseta are closely related to $B$. typica. $B$. congenera can be distinguished from $B$. typica, because the caudal rami are as long as wide and with $670 \mu \mathrm{m}$ is this species a bit smaller than B. typica $(730-1,080 \mu \mathrm{m}$; mean $=860 \mu \mathrm{m})$. Sars $(1920)$ described the female anten- nule of $B$. congenera as eight-segmented, however, his drawing is not clear and no other Ectinosomatidae has more than seven segments. B. minutiseta can be distinguished from B. typica, because the caudal rami are as long as wide, the smaller body size $(435-510 \mu \mathrm{m})$, and the small outer seta of the baseoendopod of P5 (hence the species name), 


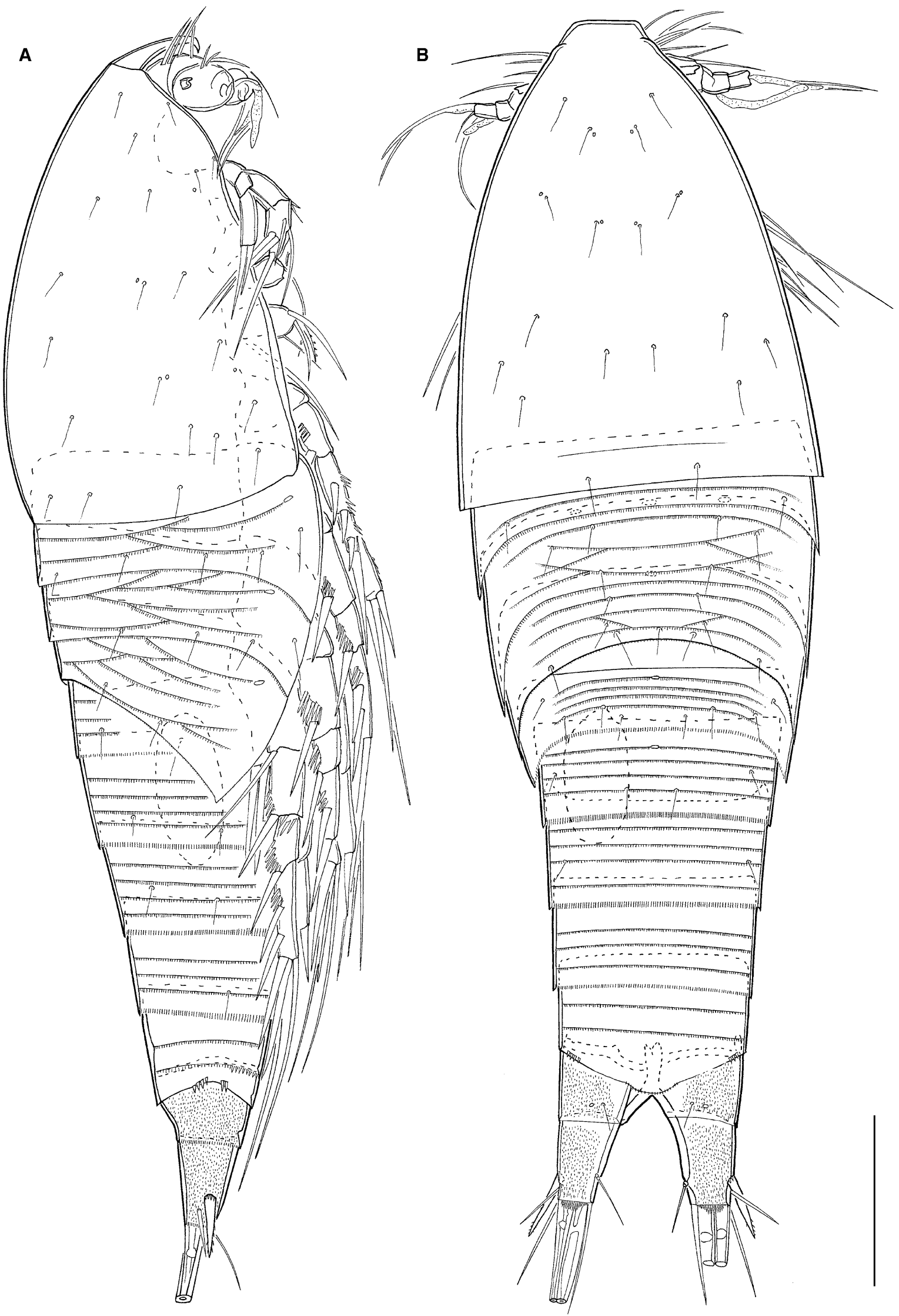

Fig. 10 Bradya typica Boeck, 1873, male 1: a habitus lateral; see paragraph "Note"; $\mathbf{b}$ habitus dorsal; see paragraph "Note. Scale bar = $100 \mu \mathrm{m}$ 


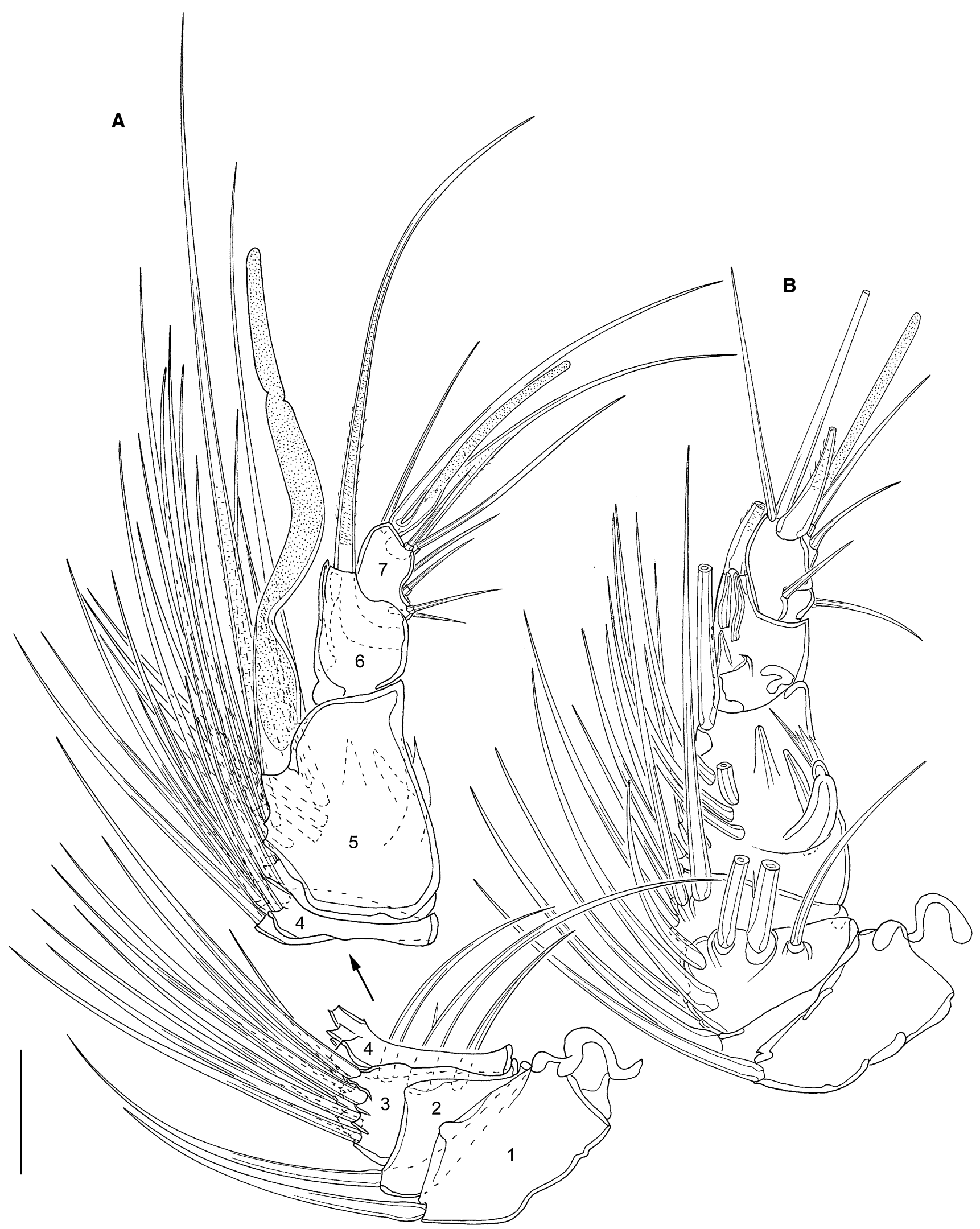

Fig. 11 Bradya typica Boeck, 1873, male 1: a left antennule, ventral; $\mathbf{b}$ dorsal view of right antennule, ventral setae omitted. Scale bar $=20 \mu \mathrm{m}$ 


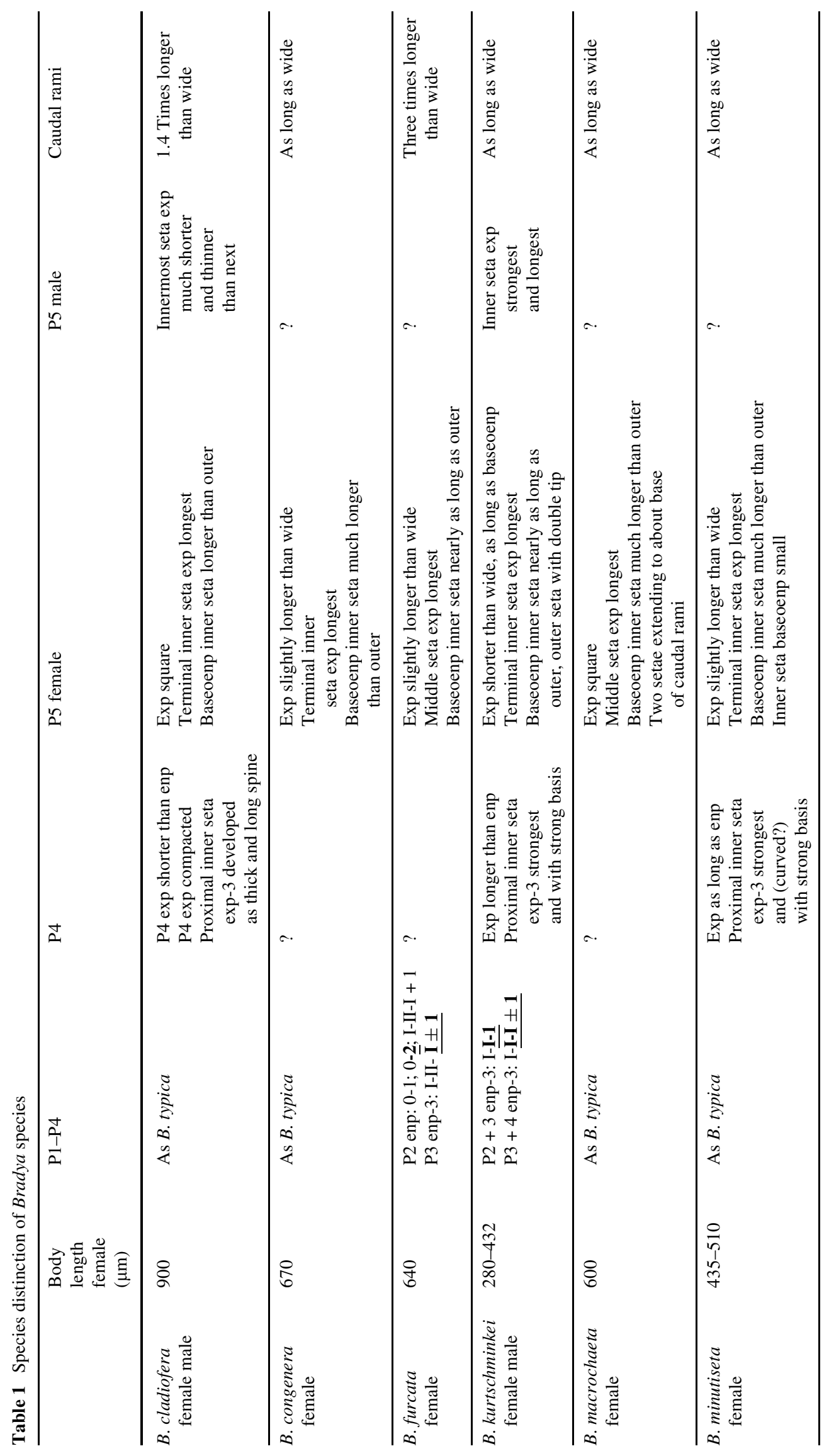




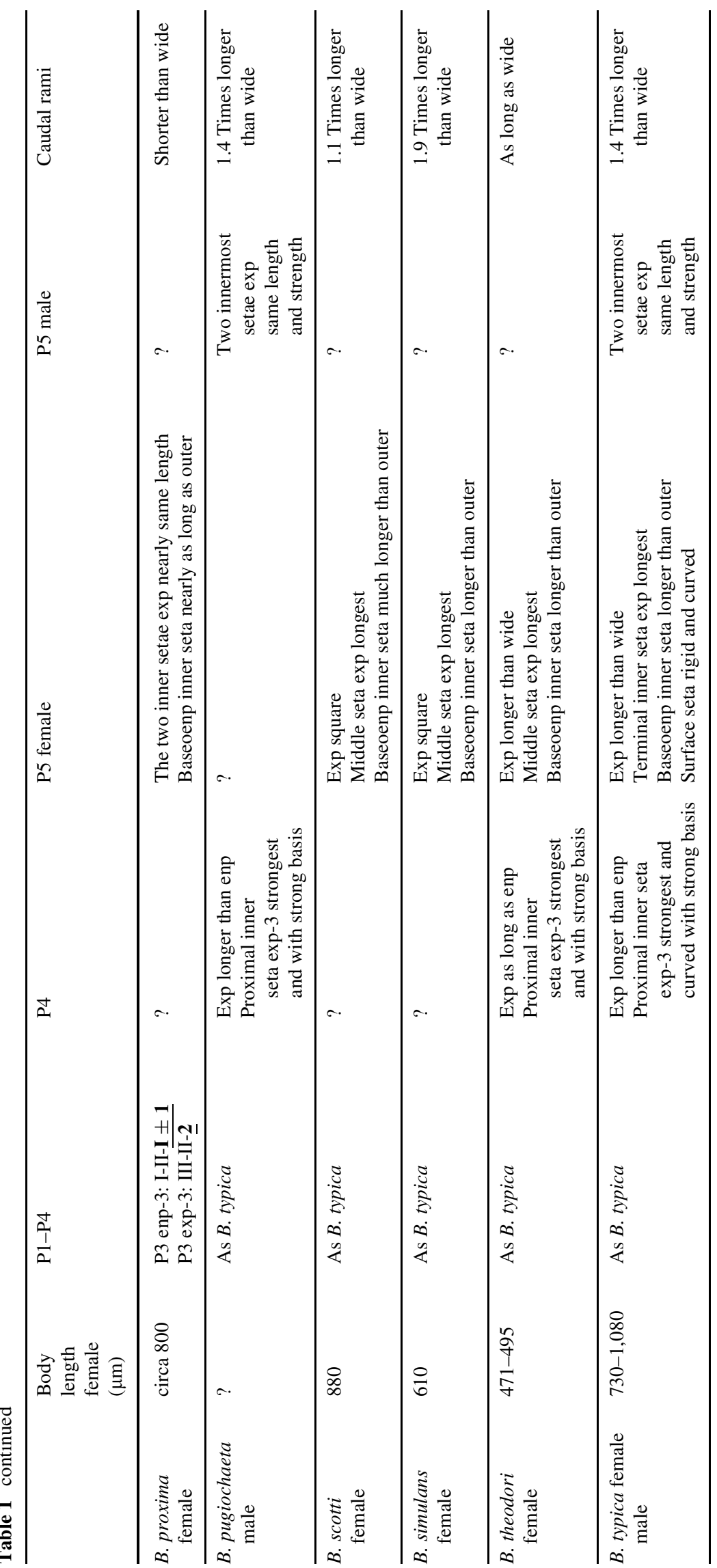


that reach not far beyond the exopod. The differences between B. cladiofera and B. typica are so small that these species are difficult to distinguish, even the body length is within the same range. Lang (1965) wrote that "the length of the first four pairs of legs of this species [B. typica], and the proportions of their segments, are quite different from those of B. cladiofera." However, we could only see the difference in P4, not in P1-P3. In B. cladiofera, the exopod of $\mathrm{P} 4$ is shorter than the endopod but in B. typica the exopod is longer. Furthermore, the exopod and to a lesser degree the endopod of P4 in B. cladiofera are more compacted. The proximal inner seta of exp-3 of P4 is transformed into a curved seta with a strong basis in B. typica (Fig. 8b) and into a thick and long spine in B. cladiofera. It is also evident that the setae and spines of P1-P4 are a bit shorter in B. cladiofera. The female exopod of P5 is square in B. cladiofera and longer than wide in B. typica. The two innermost setae of the male exopod are different: the setae have nearly the same length and strength in B. typica, whereas the innermost is much shorter and thinner in B. cladiofera. Lang (1965) did not figure the lateral and dorsal views of the female habitus of $B$. cladiofera and the ventral ornamentation of the abdomen was not completely drawn. Although it is not possible to compare in every detail, the ornamentation of the ventral abdomen in females is maybe the same as in B. typica, assuming that Lang (1965) did not draw the very fine rows of small setules on the genital somite and the two following somites and the small spinules covering the anal somites and the caudal rami, but they are present (as in the male of $B$. cladiofera, see below). The ventral row of spinules of the genital somite and the two following somites are maybe bigger in B. typica (Fig. 2a), but this is possibly a drawing artefact. The abdomen of the male of $B$. cladiofera is figured in dorsal, lateral and ventral view (Lang 1965). The male has the rows of small setules on the first to fifth urosomal somites, but the anal somite and the caudal rami are drawn without small spinules. The only evident difference in ornamentation between B. typica and B. cladiofera is the size of the ventral row of spinules of the second to fifth urosomal somites in the male as they are bigger in B. typica and there is space between the spinules (Fig. 2e).

For B. pugiochaeta (classified as Bradya see Seifried et al. 2007), only the male is described. The single male described by Arlt (1983) from the Kattegat resembles in the described parts the to-date undescribed male of B. typica, especially the P5 is the same. B. typica was found in the East Skagerak (Gullmar Fjord, Lang 1948) and in the Öresund (South of Kattegat; Lang 1936b), so that it is conceivable that B. pugiochaeta from the Kattegat is the male of $B$. typica, but this remains to be confirmed.

Differences between the descriptions of these species in some other characters, as for example the setation of the antennule, the endopod of the mandible, the allobasis of the maxilla or the arthrite and basis of the maxillule, can may be explained by deficient drawings and incorrect setae numbers.

\section{Groundpattern of Ectinosomatidae}

The groundpattern of Ectinosomatidae was reconstructed by Seifried (2003), and additional characters were added by Seifried et al. (2007) and Seifried and Martínez Arbizu (2008). Some more can be derived from the male antennule of B. typica, which has an armature formula of $1,1,12,8$, $15+$ aes $/ 4,9+$ aes. One of the 15 setae on the fifth segment is the cuticular cone of the male antennule, which comprises two cuticular conical apophyses and a unipinnate seta (Fig. 9c) and is present in every species of Ectinosomatidae (Seifried 2003). This cuticular cone was not yet counted as a seta in the armature formula in Seifried (2003), Seifried et al. (2007), and Seifried and Martínez Arbizu (2008). Taking into account the armature formula of the male antennule in B. typica, the groundpattern of the seven-segmented male antennule of Ectinosomatidae is 1, $1,12,9,15+$ aes $/ 4,11+$ aes, as there are one more seta on the second segment and three more setae on the fifth, than listed in Seifried and Martínez Arbizu (2008). Consequently, the groundpattern of the seven-segmented male antennule of Ectinosomatidae contains the same number of setae as that of the 14-segmented male antennule of Syngnatharthra Seifried and Schminke 2003 and Oligoarthra Lang 1944 (Seifried 2003; Seifried and Schminke 2003).

\section{Distribution}

On the basis of the examined material, it is sure that $B$. typica is distributed in the following areas: Spitsbergen (between $76^{\circ} 49^{\prime} \mathrm{N}-81^{\circ} 14^{\prime} \mathrm{N}$ and $15^{\circ} 22^{\prime} \mathrm{E}-27^{\circ} 39^{\prime} \mathrm{E}$, Lang $1936 \mathrm{a} ; 78^{\circ} 56.88^{\prime} \mathrm{N}, 11^{\circ} 51.63^{\prime} \mathrm{E}$, own results), polar islands north of Grinnelland (Canadian Arctic Archipelago near Baffin Bay, Sars 1910), Norway (from the Oslo Fjord to Trondheim Fjord, Boeck 1873, Sars 1904), and Sweden (Gullmar Fjord, Lang 1948; Öresund south of Kattegat, Lang 1936b). Other records are not certain, taking into account that there are no detailed drawings proving species identity and that the characters distinguishing Bradya species are very small. Scott and Scott (1894) mixed up $B$. typica with $B$. scotti, which makes their information on species' distributions ambiguous (Lang 1948). Huys et al. (1996) stated that B. typica is widely distributed around the British Islands and in the North Sea between France, Belgium, Netherlands, Germany and Norway. However, they did not give detailed information about their source.

Therefore, it can be stated with certainty that B. typica is distributed near the Norwegian coast (Oslo Fjord to 
Trondheim Fjord), the Swedish coast (Skagerak to Öresund), around Spitsbergen and the polar islands north of Grinnelland (Canadian Arctic Archipelago near Baffin Bay). Records of B. typica from the Kara Sea (near Novaya Zemlya), near Franz Joseph Land, Iceland, Greenland, the British Isles and from deep waters of the North Sea are not certain and have to be confirmed.

Bradya typica was found on mud or clay at a depth between $20 \mathrm{~m}$ (own results) and $210 \mathrm{~m}$ depth (Lang 1936a, 1948). The reports of Thompson (1889) from a muddy shore at Penmon Point, Anglesey (Wales), of Scott (1906) from an estuary in Scotland and of Jespersen (1940, in Lang 1948) from 1,074 $\mathrm{m}$ depth near Greenland need confirmation.

Acknowledgments We would like to thank Dr Jürgen Laudien, Alfred-Wegener-Institute for Polar- and Marine Research for inviting GVK to participate in the KOP 51 project at the AWIPEV station in $\mathrm{Ny}$ Ålesund, Spitsbergen. For assistance in the field and sampling Tilman Alpermann, Dr Michael Assmann, Saskia Brandt, Marko Herrmann, Dr Ricardo Sahade, Max Schwanitz, Dr Jose Velez and Hendrik Wessels are thanked. Treatment of samples and sorting was done by Jan Knott and Bianca Wenzel (DZMB, Senckenberg). We would also like to thank Karin Sindemark (Swedish Museum of Natural History, Stockholm) and Åse Wilhelmsen (Natural History Museum, Oslo) for help with museum material and the sampling locations. Sincere thanks to Professor Dr Horst Kurt Schminke for useful comments on the manuscript. Thanks are also due to Angelika Sievers for correcting the English. Three reviewers made comments that improved the original manuscript. Financial support by the Alfred P. Sloan Foundation via the Census of Marine Life (CoML) field project Arctic Ocean Diversity (ArcOD, Grant No. UAF 06-0113) is gratefully acknowledged.

\section{References}

Arlt G (1983) Taxonomy and ecology of some harpacticoids (Crustacea, Copepoda) in the Baltic Sea and Kattegat. Zool Jahrb Abt Syst 110(1):45-85

Boeck A (1873) Nye Slaegter og Arten af Saltvands-Copepoder, vol 1873. Forhandlinger i Videnskabs-Selskabet i Christiania, Christiania, pp 35-60

Huys R, Gee JM, Moore CG, Hamond R (1996) Marine and brackish water harpacticoid copepods. Part 1. In: Kermack DM, Barnes RSK, Crothers JH (eds) Synopses of the British Fauna (New series), London

Jespersen P (1940) Non-parasitic Copepoda. Zool Iceland 3(33):1-116

Lang K (1936a) Die während der schwedischen Expedition nach Spitsbergen 1898 und nach Grönland 1899 eingesammelten Harpacticiden. K Sven Vet Akad Handl 3,15(4):1-55
Lang K (1936b) Undersökningar över Öresund. Untersuchungen aus dem Öresund. XX. Harpacticiden aus dem Öresund. Acta Univ Lund 2,31(8):1-52

Lang K (1944) Monographie der Harpacticiden (Vorläufige Mitteilung). Almquist \& Wiksells Boktryckeri Ab, Uppsala

Lang K (1948) Monographie der Harpacticiden I + II. Håkan Ohlssons Boktryckeri, Lund

Lang K (1965) Copepoda Harpacticoida from the Californian Pacific coast. K Sven Vet Akad Handl 10(2):1-566

Sars GO (1903) An account of the Crustacean of Norway. Copepoda Harpacticoida 5(Pt I-II): 1-28

Sars GO (1904) An account of the Crustacea of Norway. Copepoda Harpacticoida 5(Pt III-VI):29-56

Sars GO (1910) An account of the Crustacea of Norway. Copepoda Harpacticoida 5(Pt XXIX-XXX):337-368

Sars GO (1920) An account of the Crustacea of Norway. Copepoda Suppl 7(Pt VII-VIII):73-92

Scott T (1906) A catalogue of land, fresh-water, and marine Crustacea found in the basin of the River Forth and its estuary. Part II. The Ostracoda, Copepoda, and Cirripedia. Proc R Phys Soc Edinb 16(7):267-386

Scott (1912) The Entomostraca of the Scottish National Expedition, 1902-1904. Trans R Soc Edinb 48(3):521-599

Scott T, Scott A (1894) A revision of the British Copepoda belonging to the genera Bradya Boeck, and Ectinosoma Boeck. Trans Linn Soc Lond Zool Ser 2 6(5):419-446

Seifried S (2003) Phylogeny of Harpacticoida (Copepoda): Revision of "Maxillipedasphalea" and Exanechentera. Cuvillier Verlag, Göttingen

Seifried S, Martínez Arbizu P (2008) A new and exceptional species of Bradya Boeck, 1873 (Copepoda: Harpacticoida: Ectinosomatidae) from the abyssal plain of the Angola Basin and the variability of deep-sea Harpacticoida. Zootaxa 1866:303-322

Seifried S, Schminke HK (2003) Phylogenetic relationships at the base of Oligoarthra (Copepoda, Harpacticoida) with a new species as the cornerstone. Org Divers Evol 3:13-37

Seifried S, Plum C, Schulz M (2007) A new species of Parabradya Lang, 1944 (Copepoda: Harpacticoida: Ectinosomatidae) from the abyssal plain of the Angola Basin. Zootaxa 1432:1-21

Soyer J (1973) Contribution a l'etude des copepodes harpacticoides de mediterranee occidentale. 7. Le genre Bradya Boeck (Ectinosomidae Sars, Olofsson). Syst Ecol Vie Milieu 23:327-342

Thompson IC (1889) Third report on the Copepoda of Liverpool Bay (the L.M.B.C. District). Proc Liverp Biol Soc 3:181-191

Veit-Köhler G, Laudien J, Knott J, Sahade R (2006) Meiobenthic assemblages colonizing artificial soft sediments at $20 \mathrm{~m}$ depth in Arctic glacial Kongsfjorden, Spitsbergen, Svalbard. doi:pangaea. de/10.1594/PANGAEA.552218

Veit-Köhler G, Laudien J, Knott J, Velez J, Sahade R (2008) Meiobenthic colonisation of soft sediments in arctic glacial Kongsfjorden (Svalbard). J Exp Mar Biol Ecol 363:58-65 